\title{
Measurements of Hand and Foot - A Predictor of Stature in Adult Human Population of Uttar Pradesh
}

\author{
RATI TANDON, SYED MOBASHIR YUNUS, NAFIS AHAMED FARUQI, ADIL ASGHAR
}

\section{ABSTRACT}

Introduction: The stature of human can be easily determined by femoral length, cephalometric measurements and other long bone's length. In many studies, use of soft tissue measurement like lower limb, upper limb and arm span also well correlated with height of the person.

Aim: To investigate the association of hand and foot length with height and prediction of height using hand and foot morphometrics.

Materials and Methods: 238 males and 259 females in the age group of 18-30 year were considered for measurements: height, hand morphometrics and foot morphometrics. Stadiometer was used to measure the height. All morphometric measurements analyzed by SPSS.
Results: In females, stature varied from 140.500 to 180.00 $\mathrm{cm}$ with mean value of $157.199 \pm 6.244 \mathrm{~cm}$. In males, stature varied from 159.00 to $190.00 \mathrm{~cm}$ with mean value of 172.742 $\mathrm{cm} \pm 6.110 \mathrm{~cm}$. The mean height of subject is $164.642 \pm$ $9.926 \mathrm{~cm}$. The mean hand length, hand breadth, middle finger length, thumb length, foot length and foot breadth are $18.304 \pm 1.458 \mathrm{~cm}, 7.757 \pm 0.688 \mathrm{~cm}, 7.528 \pm 0.597 \mathrm{~cm}$, $6.092 \pm 0.543 \mathrm{~cm}, 24.728 \pm 1.927 \mathrm{~cm}$, and $9.402 \pm 0.819$ respectively.

Conclusion: Foot length is better predictor of stature than hand length. Using regression formula the height of subject can be easily determined and this will be used as research tool in anthropological and medicolegal issues.

\section{INTRODUCTION}

The stature of an individual is an inherent characteristic which varies with race and is determined by genetic constitution of a person, geographical location, environment and climatic conditions [1]. With increasing frequency of mass disasters, it is essential to find out correlations between stature, age and sex of an individual with variable information collected from different systems, organs or its parts which is of immense importance. Several scientists established correlation between hand and foot measurements with stature [2-4]. The most interesting part of all these studies was regional and racial considerations while predicting the stature from different measurements. A large number of Indian scientists also have explored the study of stature determination in population samples of different regions and casts. Bhavna and Nath [5] used lower limb measurements in reconstructing stature among Shia Muslims. Sen and Ghosh [6] estimated stature from foot length and foot breadth among the Rajbhanshi, an indigenous population of North Bengal. Studies are also available from a population of West India [7, 8] as well as the population of South India [9]. Studies in population of North Indians are scanty. The aim of the present study was to consider the following measurements in a population sample from Uttar Pradesh i.e. hand length, hand breadth, thumb length, middle finger length, foot length and foot breadth and correlate them with stature. To calculate the height from hand and foot measurements, regression formulae were established in the whole sample (combined population), in male and female samples separately (sexual dimorphism). Such formula will be of great use in medicolegal cases.

\section{MATERIALS AND METHODS}

This cross sectional study was undertaken in the Department of Anatomy, JN Medical College Aligarh, between 2010 to 2014 after approval of Institutional ethics committee. Inform consent taken from each subject. The inclusion criteria were age > 18 years, Body mass index 19-23, resident of Uttar Pradesh. Exclusion criteria were chronic illness, On hormonal therapy, kyphosis, pathological scoliosis, hand or foot abnormalities [10] . Subjects were selected from the medical students comprising of 238 males and 259 females in the age group of 18-30 years following parameters were considered for measurements: height, hand morphometrics (hand length, hand breadth, middle finger length, thumb length) and foot 
morphometrics (foot length, foot breadth). Stadiometer was used to measure the height. The $L$ - shaped scale was used to measure the lengths of hand and foot. Vernier callipers was used to measure the hand breadth, middle finger length, thumb length, foot breadth. Height (stature) is the vertical distance from the vertex of the plantar surface of the heel while the subject standing erect on the horizontal resting plane, barefoot. Hand length was measured from the level of the tip of the styloid process of the radius to the tip of the middle finger. Hand breadth is the distance between metacarpal radiale (the most prominent point outside of the lower epiphysis of $2^{\text {nd }}$ metacarpal) to metacarpal ulnare (the most prominent inside of the lower epiphysis of the metacarpal). Thumb length is the distance from the proximal point (phallangion) noted by palpating the metacarpo-phalangeal joint to the distal most point of thumb (Dactylion). Middle finger length is the distance from the most proximal flexion crease of the middle finger, till the projecting point on tip of finger. Foot length is the distance from the most prominent part of the heel backward (pternion) to most distal part of longest toe i.e. $2^{\text {nd }}$ or $1^{\text {st }}$ (acropodion). Foot breadth is the distance between metatarsal tibiale (most medially projecting point on the head of the $1^{\text {st }}$ metatarsal bone and metatarsal fibulare, most laterally projecting point on the head of the $5^{\text {th }}$ metatarsal bone). Each measurement was considered by a mean of 3 measurements by two investigators and intra-observer and inter-observer reliabilities were $99.4 \%$ and $98.9 \%$.

Different measurements of hand and foot were calculated and correlated with the stature and the data were, statistically analyzed, to formulate a regression equation for the determination of stature using SPSS 17 Software [Table/ Fig-1].

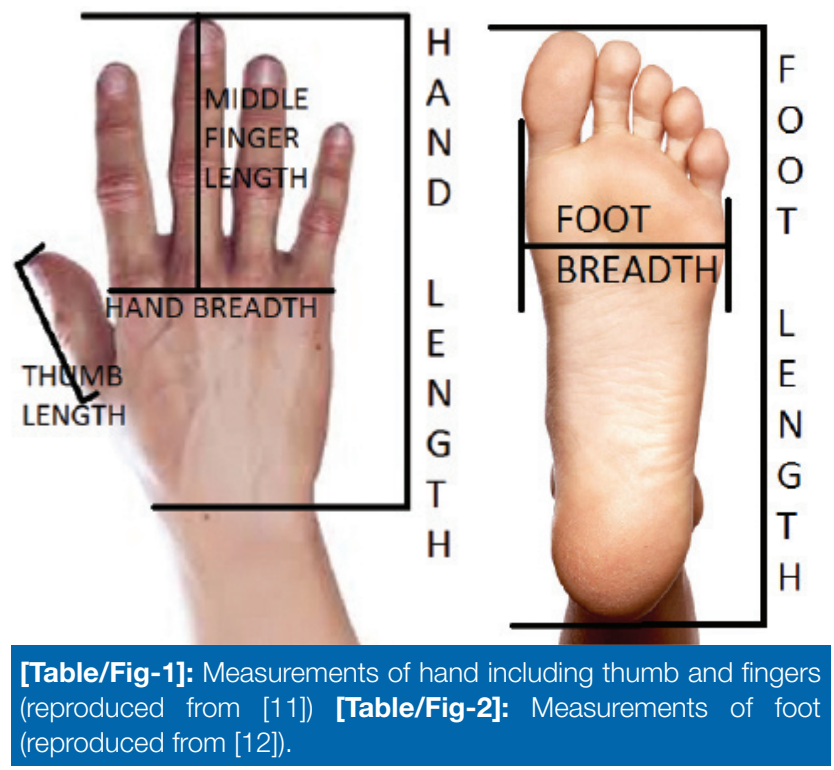

\section{RESULTS}

In females, stature varied from 140.500 to $180.00 \mathrm{~cm}$ with a mean value of $157.199 \mathrm{~cm}$ and standard deviation of $6.244 \mathrm{~cm}$ but males having significantly higher value, stature varied from 159.00 to $190.00 \mathrm{~cm}$ with a mean value of $172.742 \mathrm{~cm}$ and standard deviation of $6.110 \mathrm{~cm}$. $(p=0.0027)$. The hand length and foot length $(r>0.85)$ are better correlated to hand breadth, foot breadth and middle finger length $(r<0.7)$. All parameters having significant higher value in male than female.

\section{DISCUSSION}

Hand and foot parameters have long been used for determination of stature [13-16]. Studies have shown that hand dimensions vary in different races. The Nigerian female hand was found to be wider and shorter than that of their foreign counterparts [17]. We devised the linear regression equations as well as correlation for the estimation of stature from different measurements of hand and foot. Descriptive analysis of hand length of male, female and complete sample $(\mathrm{cm})$ is mean \pm SD: $19.364 \pm 1.097 ; 17.33 \pm 0.997$ and $18.304 \pm 1.458$ respectively. The regression formulae for aforementioned three samples were: $y=3.16 x+111.5 ; y=3.504 x+96.46$ and $y$ $=5.07 x+71.67$ respectively. Rastogi et al., [17] calculated hand length on both the sides and in both the sexes in north and south Indian populations. They found a highly significant correlation between hand length and height of the individual. A striking feature of the two studies was different equations for different samples and in both sexes. This highlights the need of formulation of the regression equations for different regions, races and both sides and sexes. Hand breadth measured in the present study has been conducted in 497 individuals (238 males and 259 females). Descriptive analysis of male, female and complete sample $(\mathrm{cm})$ were: Mean \pm SD: 8.312 $\pm 0.414 ; 7.247 \pm 0.457$ and $7.757 \pm 0.688$ respectively. The regression formulae for aforementioned three samples were: $y$ $=5.79 x+124.54 ; y=7.125 x+105.5$ and, $y=11.36 x+76.49$ respectively. Correlation of determination $\left(R^{2}\right)$ for male, female and complete sample $=0.154,0.272$ and 0.621 respectively. $A$ study based on measurements of hand breadth and height of total 300 students (147 males and 153 females) was done by Chikhalkar et al., [18]. They found a single regression equation for calculating height from hand breadth, i.e. $y=113.561732$ $+7.139216 x$. For calculating height, we used higher number of population and formed different regression equations using hand breadth, with different values, resulting in more correct regression equations in Uttar Pradesh population. Descriptive analysis of middle finger length of male, female and complete sample $(\mathrm{cm})$ were: Mean \pm SD: $7.913 \pm 0.469 ; 7.174 \pm 0.471$ and $7.528 \pm 0.597$ respectively. Rastogi et al., [19] showed that the middle finger length bears a significant relation to stature and can be an important tool for stature estimation. 
Shivakumar et al., [20] estimated correlation between middle finger length \& stature in 100 females of Karnataka, South Indian population, The present study was done in north Indian population and higher number of individuals $(n=500)$ were taken into consideration. Separate linear regression equations for height estimation using MFL were formulated for males and females. Descriptive analysis of thumb length of male, female and complete sample $(\mathrm{cm})$ were: Mean \pm SD: $6.470 \pm 0.423$, $5.774 \pm 0.387$ and $6.092 \pm 0.543$ respectively. Male, female and complete sample were: $y=9.41 x+111.79 ; y=7.919 x+$ 111.7 andy $=14.37 x+77.09$ respectively. Verghese et.al. [10] estimated stature using length of fingers in Mysore. The sample consisted of 50 males and 50 females. The best finger to predict the height in case of males was found to be the left thumb and in case of females it was the right thumb. We used sample size $(n=500)$, which was very large. Regression formulae using thumb length were obtained for separate groups. Descriptive analysis for foot length of male, female and complete sample $(\mathrm{cm})$ were: Mean \pm SD: $26.227 \pm 1.330 ; 23.35 \pm 1.238$ and 24. $728 \pm 1.927$ respectively [Table/Fig-2-6]. The regression formulae for male, female and complete sample were: $y=3.09 x$ $+91.46 ; y=2.896 x+89.55$ and $y=4.33 x+57.34$ respectively. A study based on measurements of foot length and body

\begin{tabular}{|l|l|c|c|c|c|l|}
\hline $\begin{array}{c}\text { S. } \\
\text { No. }\end{array}$ & Parameters & $\begin{array}{c}\text { Sample } \\
\text { Size(f) }\end{array}$ & $\begin{array}{c}\text { Mean } \pm \text { SD } \\
\text { (female) }\end{array}$ & $\begin{array}{c}\text { Sample } \\
\text { Size(m) }\end{array}$ & $\begin{array}{c}\text { Mean } \pm \text { SD } \\
\text { (male) }\end{array}$ & p value \\
\hline 1. & Height & 259 & $\begin{array}{c}157.199 \\
\pm 6.244\end{array}$ & 238 & $\begin{array}{c}172.742 \\
\pm 6.110\end{array}$ & 0.0027 \\
\hline 2. & Hand length & 259 & $\begin{array}{c}17.33 \pm \\
0.997\end{array}$ & 238 & $\begin{array}{c}19.364 \\
\pm 1.097\end{array}$ & 0.0003 \\
\hline 3. & Hand breadth & 259 & $\begin{array}{c}7.247 \pm \\
0.457\end{array}$ & 238 & $\begin{array}{c}8.312 \pm \\
0.414\end{array}$ & 0.0016 \\
\hline 4. & Middle finger & 259 & $\begin{array}{c}7.174 \pm \\
0.471\end{array}$ & 238 & $\begin{array}{c}7.913 \pm \\
0.469\end{array}$ & 0.0071 \\
\hline length & Thumb length & 259 & $\begin{array}{c}5.774 \pm \\
0.387\end{array}$ & 238 & $\begin{array}{c}6.470 \pm \\
0.423\end{array}$ & 0.0083 \\
\hline 6. & Foot length & 259 & $\begin{array}{c}23.35 \pm \\
1.238\end{array}$ & 238 & $\begin{array}{c}26.227 \\
\pm 1.330\end{array}$ & 0.0009 \\
\hline 7. & Foot breadth & 259 & $\begin{array}{c}8.89 \pm \\
0.583\end{array}$ & 238 & $\begin{array}{c}9.953 \pm \\
0.670\end{array}$ & 0.0043 \\
\hline
\end{tabular}

[Table/Fig-3]: Descriptive statistics for stature and measurements (cm) of hands and feet in female and male sample.

\begin{tabular}{|c|l|c|c|}
\hline S.No. & \multicolumn{1}{|c|}{ Parameters } & Regression equations & $\mathrm{R}^{2}$ \\
\hline 1. & Hand length & $\mathrm{y}=3.504 \mathrm{x}+96.46$ & 0.313 \\
\hline 2. & Hand breadth & $\mathrm{y}=7.125 \mathrm{x}+105.5$ & 0.272 \\
\hline 3. & Middle finger length & $\mathrm{y}=6.478 \mathrm{x}+110.7$ & 0.238 \\
\hline 4. & Thumb length & $\mathrm{y}=7.919 \mathrm{x}+111.7$ & 0.241 \\
\hline 5. & Foot length & $\mathrm{y}=2.896 \mathrm{x}+89.55$ & 0.330 \\
\hline 6. & Foot breadth & $\mathrm{y}=3.684 \mathrm{x}+124.4$ & 0.118 \\
\hline
\end{tabular}

[Table/Fig-4]: Regression equations to determine height from different parameters in female sample. height of in 300 students (147 males and 153 females) was done by Chikhalkar et al., [16]. They formulated found the single regression equation for calculating height from hand length i.e. $y=114.828119+5.906901 x$. In the present study, we have formulated regression equations separately for both the sexes and for complete population to make stature estimation more accurate. Foot breadth was another parameter used for calculating height. The present study was conducted in 497 individuals (238 males and 259 females). Descriptive analysis of male, female and complete sample $(\mathrm{cm})$ Mean \pm SD were: $9.953 \pm 0.670 ; 8.89 \pm 0.583$ and $9.402 \pm 0.819$ respectively. The regression formulae for male, female and complete samples were: $y=4.55 x+127.39 ; y=3.684 x+124.4$ and $y=4.33 x$ +57.34 respectively. A study based on measurements of foot breadth and height in total 300 students (147 malesand 153 females) was done by Chikhalkar et al., [16] in individuals of Mumbai population. They found a single regression equation for calculating height from foot breadth, i.e. $y=114.828119+$ $5.906901 x$. In the present study, we had formulated different regression equations separately for both the sexes and for complete population of Uttar Pradesh. Foot dimensions have better correlation with the stature than hand dimensions. Foot length was a better parameter to estimate stature $[14,16]$.

\begin{tabular}{|c|l|c|c|}
\hline S.No. & \multicolumn{1}{|c|}{ Parameters } & Regression equations & $\mathrm{R}^{2}$ \\
\hline 1. & Hand length & $\mathrm{y}=3.16 \mathrm{x}+111.5$ & 0.224 \\
\hline 2. & Hand breadth & $\mathrm{y}=5.79 \mathrm{x}+124.54$ & 0.154 \\
\hline 3. & Middle finger length & $\mathrm{y}=6.83 \mathrm{x}+118.66$ & 0.275 \\
\hline 4. & Thumb length & $\mathrm{y}=9.41 \mathrm{x}+111.79$ & 0.425 \\
\hline 5. & Foot length & $\mathrm{y}=3.09 \mathrm{x}+91.46$ & 0.455 \\
\hline 6. & Foot breadth & $\mathrm{y}=4.55 \mathrm{x}+127.39$ & 0.250 \\
\hline
\end{tabular}

[Table/Fig-5]: Regression equations to determine height from different parameters in male sample.

\begin{tabular}{|l|l|c|c|c|c|}
\hline $\begin{array}{c}\text { S. } \\
\text { No. }\end{array}$ & Parameters & $\begin{array}{c}\text { Sample } \\
\text { size }\end{array}$ & Mean \pm SD & $\begin{array}{c}\text { Regression } \\
\text { equations }\end{array}$ & $\mathrm{R}^{2}$ \\
\hline 1. & Height & 497 & $\begin{array}{c}164.642 \pm \\
9.926\end{array}$ & - & - \\
\hline 2. & Hand length & 497 & $\begin{array}{c}18.304 \pm \\
1.458\end{array}$ & $\begin{array}{c}\mathrm{y}=5.07 \mathrm{x}+ \\
71.67\end{array}$ & 0.631 \\
\hline 3. & Hand breadth & 497 & $\begin{array}{c}7.757 \pm \\
0.688\end{array}$ & $\begin{array}{c}\mathrm{y}=11.36 \mathrm{x} \\
+76.49\end{array}$ & 0.621 \\
\hline 4. & Middle finger & 497 & $\begin{array}{c}7.528 \pm \\
0.597\end{array}$ & $\begin{array}{c}\mathrm{y}=12.14 \mathrm{x} \\
+73.18\end{array}$ & 0.534 \\
\hline 5. & Thumb length & 497 & $\begin{array}{c}6.092 \pm \\
0.543\end{array}$ & $\begin{array}{c}\mathrm{y}=14.37 \mathrm{x} \\
+77.09\end{array}$ & 0.619 \\
\hline 6. & Foot length & 497 & $\begin{array}{c}24.728 \pm \\
1.927\end{array}$ & $\begin{array}{c}\mathrm{y}=4.33 \mathrm{x}+ \\
57.34\end{array}$ & 0.709 \\
\hline 7. & Foot breadth & 497 & $\begin{array}{c}9.402 \pm \\
0.819\end{array}$ & $\begin{array}{c}\mathrm{y}=4.33 \mathrm{x}+ \\
57.34\end{array}$ & 0.497 \\
\hline
\end{tabular}

[Table/Fig-6]: Regression equations to determine height from different parameters in complete sample 


\section{CONCLUSION}

In all parameters the foot length and hand length are better predictors of stature in both sex. These regression formula can be used for adult between 18-35 years but it might be of limited use for children and older people for measuring the stature and shoe design. The data will be helpful for standardizing data for epidemiological purpose or where stature determination objectively is needful.

\section{REFERENCES}

[1] Abdel-Malek AK, Ahmed AM, Sharkawi SAA, Hamid NMA. Prediction of stature from hand measurements. Forensic SCi Int. 1990; 46(3):181-87.

[2] Kanchan T, Krishan K, Sharma A, Menezes RG. A study of correlation of hand and foot dimensions for personal identification in mass disasters. Forensic Sci Int. 2010; 199(112): I-6.

[3] Illayperuma I, Nanayakkara G, Palahepitiya N. Prediction of personal stature based on the hand length. Galle Medical J. 2009; 14(1): 15-18.

[4] Agnihotri AK, Purwar B, Googoolye K et al. Estimation of stature by foot length. J Forensic Leg Med. 2007;14(5): 279-83.

[5] Bhavna and Nath S. Use of lower limb measurements in reconstructing stature among Shia muslims. Int J of Biological Anthropology. 2009; 2(2): 86-97.

[6] Sen J and Ghosh S. Estimation of stature from foot length and foot breadth among the Rajbhanshi: an indigenous population of West Bengal. Forensic Sci Int. 2008; 181(1): 55-56.

[7] Patel SM, Shah GV, Patel SV. Estimation of height from measurements of foot length in Gujarat region. J Anatomy Soc India. 2007; 56(1): 25-27.

[8] Chavan SK, Chavan KD, Mumbre SS et al. Stature and percutaneous tibial length: A correlational study in maharashtrian population. J of Indian Academy of Forensic Medicine and Pathology. 2009; 2(3): 334-37.

[9] Verghese AJ, Balaraj BM, Kumar PGN. A study of estimation of stature from length of fingers in Mysore. Indian $\mathrm{J}$ of Forensic
Medicine Toxicology. 2010; (4)2: 26-30.

[10] Keshavachandran CN, Bihari V, Mathur N The normal range of body mass index with high body fat percentage among male residents of Lucknow city in north India. Indian J Med Res. 2012; 135(1): 72-77.

[11] Oommen A, Mainker A, Oommen T: A Study of the correlation between hand length and foot length In humans. J.Anat.Soc. India; 2005; 54 (2) :1-9.

[12] Tsung BYS, Zhang M, Fan YB, Boone DA, Quantitative comparison of plantar foot shapes under different weightbearing conditions. Journal of rehablitation research and development. 2003;40 (6): 517-26.

[13] Rani M, Tyagi AK, Ranga VK, Rani $Y$ et al. Stature estimation from foot dimensions. J Punjab Acad Forensic Med Toxicology. 2011; 11(1):26-30.

[14] Sunil, Dikshit PC, Aggarwal A et al. Estimation of stature from hand length. JIAFM. 2005; 27 (4): 219-21.

[15] Laila SZH, Ferdousi R, Nurunnobi ABM, Islam SZH et.al. Anthropometric measurements of the hand length and their correlation with the stature of Bengali adult Muslim females. Bangladesh Journal of Anatomy. 2009; 7(1): 10-13.

[16] Krishan $\mathrm{K}$ and Sharma A. Estimation of stature from dimensions of hands and feet in a North Indian population. J Forensic and Legal Med. 2007; 14(6): 327-32.

[17] Rastogi P, Nagesh KR and Yoganarasimha K. Estimation of stature from hand dimensions of North and South Indians, Leg Med. 2008; 10(4): 185-89.

[18] Chikhalkar BG, Mangaonkar AA, Nanandkar SD, Peddawad RG. Estimation of stature from measurements of long bones, hand and foot dimensions. J Indian Acad Forensic Med. 2009; 32(4): 329-330.

[19] Rastogi P, Kanchan T, Menezes RG, Yoganarasimha K. Middle finger length - a predictor of stature in the Indian population. Med Sci Law. 2009; 49(2): 123-26.

[20] Shivakumar AH, Vijaynath $\vee$ and Raju GM. Estimation of corelation between middle finger length \& stature of females in South Indian population. Indian Journal of Forensic Medicine \& Toxicology. 2011; 5(1): 75-76.
AUTHOR(S):
1. Dr. Rati Tandon
2. Dr. Syed Mobashir Yunus
3. Dr. Nafis Ahamed Faruqi
4. Dr. Adil Asghar

\section{PARTICULARS OF CONTRIBUTORS:}

1. Junior Resident, Department of Anatomy, JN Medical College Aligarh, India.

2. Professor, Department of Anatomy, JN Medical College Aligarh, India.

3. Professor, Department of Anatomy, JN Medical College Aligarh, India
4. Assistant Professor, Department of Anatomy, UPRIMSR Saifai Etwah, India.

\section{NAME, ADDRESS, E-MAIL ID OF THE CORRESPONDING AUTHOR:}

Dr. Adil Asghar,

106 G Block Type 3 UPRIMSR New Campus, Etawah,

Uttar Pradesh-206130, India.

E-mail: dr_adilasghar2003@yahoo.co.in

FINANCIAL OR OTHER COMPETING INTERESTS: None.

Date of Publishing: Jan 05, 2016 